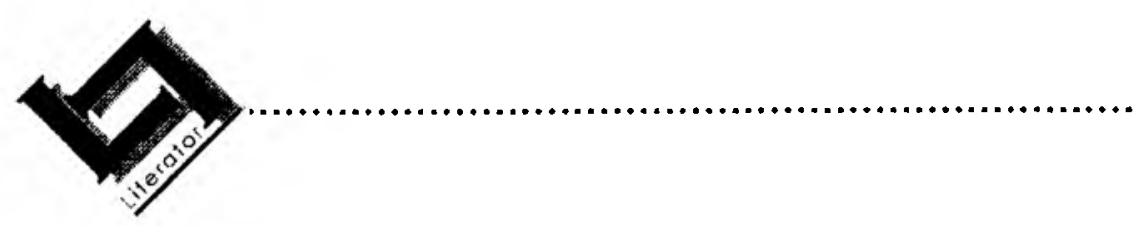

\title{
The rhetoric of conflict and conflict by rhetoric: Ireland and the Anglo-Boer War ${ }^{1}$ (1899-1902)
}

\author{
Andries Wessels \\ Department of English \\ University of Pretoria \\ PRETORIA \\ E-mail: awessels@postino.up.ac.za
}

\begin{abstract}
The thetoric of conflict and conflict by rhetoric: Ireland and the AngloBoer War (1899-1902)

This article investigates the historical context of Irish involvement in the AngloBoer War, but focuses on the literary products - mainly popular ballads and partisan historiography - of this involvement. Irish soldiers participated on both sides of the war, not so much because of identification with South African issues as because it afforded them the opportunity of fighting Irish fights on a displaced battle-field. The war thus presages the explosion of Irish/British strife in 1916 and the subsequent Irish Civil War by more than a decade. As in most wars, the struggle was conducted by the pen and by the sword and the popular Irish verse of the time reveals the sentiments of fervent Irish imperialists, defending the causes of Empire, fervent lrish nationalists espousing the Boer cause, as well as movingly suggesting the dilemma of the majority of Irish combatants, fighting for England while sympathizing with the Boers.
\end{abstract}

\section{Introduction: Irish nationalism in 1899}

The outbreak of the Anglo-Boer War in 1899 had a significant effect on the Irish national movement. Irish nationalism was in a lull and needed an injection to

1 This article is based to some extent on a paper read at the XXI Conference of the International Association for the Study of Irish Literature in Goteborg, Sweden in August 1997 
stimulate it into renewed enthusiasm. The promising parliamentary offensive of the 1880s had come to naught with the fall of Parnell in 1889 and even the centenary celebrations of the 1798 Wolfe Tone uprising had proven uninspiring and lacklustre in the doldrums that followed the collapse of the parliamentary initiative (Malins \& Purkis, 1994:40, Harkness, 1995:4). The political side of Irish life appeared "sterile and bitter" (Boyce, 1995:259). Only the Gaelic League and the Gaelic Athletic Association were keeping the flame of nationalism alive (McCracken, 1995:97). Thus it was that the spectacle of another small rural people, taking up arms in South Africa against the omnipotent British Empire, evoked a sympathetic and enthusiastic response in Ireland and fired languishing dreams of resistance and independence, galvanising, as Donal McCracken put it, "Irish nationalism [to] set it on course for that crucible where Irish independence was forged" (McCracken, 1995:97). (This, incidentally, suggests an interesting parallel between Ireland and Quebec, where the outbreak of the Boer War likewise galvanized a small, god-fearing, rural people within the British Empire into nationalist action, with riots occurring in Montreal and the Ligue nationaliste being founded by Bourassa to promote the national interests of French Canadians [Lower, 1970:152] - a momentum of which the historical repercussions have still not worked themselves out.)

\section{Irish reaction to the outbreak of the war}

The sight of the Boers actively fighting for their independence shamed the Irish parliamentary party into re-forging a sense of unity (Davey, 1978:142), but it was the ordinary people, Catholic Ireland, that really took the Boer cause to its heart. Sean O'Casey comments on the mood in 1899 , when he was a young man:

Transvaal flags were in everyone's house, everyone's window, or in everyone's hand. Spontaneous processions formed in the streets, marched through the city ... often coming into collision with the irritated police. All fancy-goods shops and newsagents were filled with Boer symbols: streams of ribbons flashing the colours of England's enemies flowed through every street and sparkled in every second window. Every patriot carried in the lapel of his coat a button picture of Kruger, Steyn, Botha, Joubert, De Wet ... (O’Casey, 1949:306; McCracken, 1995:98).

So profound was the emotional impact in Ireland of particularly the person of the Boer General Christiaan de Wet, the elusive Scarlet Pimpernel of the war, that he was rumoured to be a re-incarnation of Parnell (O'Casey, 1949:306) and as late as the 1960 s a joke still circulated in Ireland about a teacher asking a school boy on a rainy day why he was late, and getting the answer, "It's de wet, sir." "My goodness", the teacher replies, "is that fellow still at large?" 
The enthusiasm and sympathy engendered for the Boers and the heroic perception of Boer leaders form a stark contrast to the more traditional caricature of the Boers as an uncouth, uncivilized, benighted people, which was circulating in the popular British Press of the time, and articulated for example by Kipling, the Bard of Empire, in his portrait of Kruger:

Cruel in the shadow, crafty in the sun

Far beyond his borders shall his teachings run

Sloven, sullen, savage, uncontrolled,

Laying on the new land evil of the old.

(Kipling, 1919:79)

Compare this to Fanny Parnell's heartfelt (Irish) wish:

Now Christ thee save Paul Kruger!

Now Christ thee save from harm,

And may the God of Joshua

Bear up thy strong arm. ${ }^{2}$

(McCracken, 1995:105)

When Paul Kruger arrived in exile in the Netherlands in 1900, he was met at the quay by Michael Davitt, presenting him with an address from the Irish people (Davey, 1978:138). In Westminster, John Redmond, leader of the Irish party declared, "The sympathy of Ireland is with the two South African Republics. We abhor this war" (O'Brien, 1910:97). Dillon, another prominent Irish Nationalist member, condemned the war as "unjust, unnecessary and cowardly" (McCracken, 1978:168). In some cases, identification with the Boer cause went to absurd lengths. Lady Gregory describes an old Irish woman begging a prospective Irish combatant not to "kill the people of my religion". On his response that the Boers were not Catholic, she replied, "They are; I know they must be Catholics, or the English would not be against them" (Gregory, 1974 [1903]: 72).

Seizing the opportunity that the war offered for Irish nationalism with characteristic fervour and rising to the occasion with flamboyant enthusiasm, was, of course, Maud Gonne, who believed that "England's difficulty [was] Ireland's opportunity" (Spies, 1980:180-81). She established the Irish Nationalist Transvaal Committee and co-opted the services of Yeats for its activities. Obediently, the poet wrote an article for the pro-Boer Freeman's Joumal in which he drew parallels between the two countries, both victims of an "Empire in whose name liberty is being suppressed in South Africa, as it was suppressed in Ireland", provoking The Times to dismiss him scornfully as one of

2 This poem was actually wntten during the First Boer War (1881), but was resurrected in 1899 and published in the Freeman's Joumal. Fanny Parnell was the sister of Charles Stewart Pamell 
Ireland's "more obscure nationalist politicians" (Cullingford, 1981:39-40). Undismayed, Gonne distributed leaflets discouraging Irish youths from joining up and Irish girls from "consorting with the soldiers of the enemy of their country" and travelled to Brussels to propose to the Transvaal envoy stationed there that Irishmen should blow up English ships by planting bombs disguised as lumps of coal in the bunkers of troop-ships (Spies, 1980:181). In Dublin she helped Arthur Griffith set up his fiercely nationalist and pro-Boer United Irishman and in New York she informed a mass-meeting that England was "the robber nation of the world. Hence it matters not what nation England is at war with, right or wrong, it is Ireland's duty to oppose"3 (Spies, 1980:181).

\section{Irish ambiguity concerning the war}

Gonne's words pin-point a significant aspect of the war for the Irish, namely that for Ireland this was an opportunity to fight Irish fights - South Africa became a battlefield by proxy for internal Irish strife, presaging the 1916 rebellion and the Irish Civil War by a decade or two. Irishmen indeed fought on both sides of the war. Thirteen Irish infantry battalions and three cavalry regiments, including such illustrious names as the Royal Irish Rifles, the Royal Irish Fusiliers, the Connaught Rangers and the Inniskilling Dragoons, comprising 28352 Irishmen - not counting officers - saw service on the side of the British Army (Davey, 1978: 44), while two Irish Brigades, comprising no more than about four hundred and fifty men, were got up to fight on the side of the Boers (McCracken, 1995:106). This provides an astonishing discrepancy in terms of the weight of sympathy and identification that was on the side of the Boers, but, of course, it reflects the historical reality of Irish involvement and perhaps subservience, within the Imperial enterprise. In his work, Contemporary Ireland (1908), the French political commentator Louis Paul-Dubois analyses the duality or ambiguity of Irish nationalism and Irish involvement in the Empire at the turn of the century. This is an extremely useful analysis because it reflects perceptions at the time and is therefore not clouded by hindsight concerning the domination and triumph of Irish nationalism since. Paul-Dubois describes the contradictions in Irish political perceptions and opinions at the time. He points out that while Irishmen expressed their loathing for the "pirate Empire", many nevertheless played a major role in administering the Empire as far afield as India, Canada and Australia, and while they felt that "the honour of the British army was saved" during the Boer War by Irish soldiers in the British Army, Irishmen were nevertheless aggressively pro-Boer throughout the war, with many county councils voting addresses of congratulation to President Kruger (Boyce, 1995:271-272). He points out that many Irishmen joined the British Army in a spirit of adventure or because it afforded a living when work was 
scarce. As far as the war itself is concerned, Paul-Dubois points out that antiEnglish feeling found expression in delight over Boer victories, while at the same time Irishmen expressed their pride in the fighting prowess of their soldiers "in a cause which was not [Ireland's] cause" (Boyce, 1995:272).

The ambiguity of Irishmen fighting within the British army while most of their compatriots sympathized with the Boers, is one of the themes that clearly emerge in the popular verse of the time. Lady Gregory reports that she personally heard wives begging their husbands leaving from Galway for South Africa with the Connaught Rangers "not to be too hard on the Boers" and a contemporary song or verse from Galway, bears out the dilemma of the ordinary Irish soldier:

When the battle fiercely rages, our boys are in the van:

How I do wish the blows they struck were for dear Ireland!

But duty calls, they must obey, and fight against the Boer,

And many a cheerful lad will fall to rise no more.

(Gregory, 1974 [1903]:75)

More explicitly, another ballad quoted by Lady Gregory states:

Those Boers can't be blamed, as you might understand;

They are trying to free their own native land,

Where they toil night and day by the sweat of their brow,

Like the farmers in Ireland that follow the plough.

Farewell to Old Ireland, we are now going away,

To fight the brave Boers in South Africa;

To fight those poor farmers we're not inclined:

God be with you, Old Ireland, we are leaving behind.

(Gregory, 1974 [1903]:75-76)

And "The Song of the Dublin Fusilier: left behind wounded to die by the British in their retreat from Dundee", transposes the scenario to the actual battle-field in South Africa, but expresses the same ambiguous sentiment:

'Charge up boys,' sez the colonel, and I charged straight up the hill

To strike down freemen battling for their right,

To make myself a murdherer, for England's sake to kill

The pathriots standin' out agin' her might.

(McCracken, 1995:104)

These verses are characterized by cliched expressions and sentiments ("dear Ireland", "Old Ireland", "duty calls", "the sweat of their brow"), by clumsy inversions for the sake of rhyme ("To fight those poor farmers we're not inclined"), as popular doggerel verse often is. The aim of the verse is clearly the expression or even mustering of mass emotion rather than any profundity of 
conception or subtlety of expression. The propagandistic elements of antiEnglish sentiment are overlaid by a thin layer of sentimental melancholy ("Farewell to Old Ireland ..."), traditionally associated with the rather maudlin popular Irish ballads, such as "Mother Machree" or "Kathleen Mavourneen". In "The Song of the Dublin Fusilier" a change is detected in that the speaker in this ballad speaks with the "Tommy Atkins" accent popularized by Kipling in his British Army stories and verse. Kipling's mythification of the British Tommy his stories and poems often strategically include representatives of the various regions in Great Britain: an Englishman, an Irishman, a Welshman and Scotsman - proved extremely effective. It has been alleged that while no British soldier actually spoke like this before Kipling wrote, they all did afterwards. The use of Tommy Atkins diction in an anti-English ballad such as "The Song of the Dublin Fusilier" is thus in itself ironic and indicative of the anomalous or at least ambiguous position of the Irish soldier fighting English fights during the age of Empire.

\section{A war of words}

These popular verses or ballads, as rhetoric of war, are an important barometer of the Irish experience of the Boer War. The significance of the conflict of rhetoric probably outweighed the significance of military participation with regard to the momentum of the broader nationalist movement at the time and thus with regard to the eventual thrust of twentieth-century Irish history. Maud Gonne has already been quoted, weighing in with some heavy artillery, but most of the war of words would be conducted by means of the kind of popular verse already cited.

The publishing of verse with a nationalist or political aim in the popular press had become a well-established and entrenched Irish tradition long before the advent of the Anglo-Boer War. In 1842, the idealistic Irish nationalist, Thomas Davis, established The Nation as a vehicle for Irish nationalism. The declared aim of this paper was to "create and foster a public opinion in Ireland and make it racy of the soil" (Boyce, 1995:159). It published nationalist verse inter alia and soon became the widest selling paper in Irish history, achieving an astonishing readership for the time of approximately a quarter of a million (Boyce, 1995:158-9). According to Charles Gavan Duffy, one of Davis's collaborators, the impact on the Irish people of the vehemently nationalistic poetic outpourings in the journal was "like electric shocks" (Brown, 1972:67). The United Irishman, edited by Arthur Griffith, the author of a number of proBoer ballads, was a fiercely and militantly nationalistic publication and therefore a natural medium for pro-Boer or anti-English rhetoric, whether in the form of reportage or ballads. Griffith had adopted the title of the newspaper to connect it symbolically to an earlier publication of the same name, which had been established in 1845 by the extremist nationalist, John Mitchel, to propagate his 
beliefs in violent insurrection (Boyce, 1995:167, 173). The Freeman's Journal, for which Michael Davitt later acted as war correspondent and in which Fanny Parnell's eulogy of Kruger (quoted earlier) appeared, was a more moderate nationalistic publication, a "model of constitutional and conservative nationalism" (Boyce, 1995:264), but it also remained uncompromisingly pro-Boer in its editorial policy. It was associated with the Irish nationalist parliamentary party, rather than with the advocates of violent rebellion. On the other hand, there was, of course, also a powerful unionist or pro-imperial Irish Press at the turn of the century, comprising publications such as the Irish Figaro, The Irish Times and the Dublin Daily Express (cf. Boyce, 1995:194), which would be eager to publish pro-war propaganda. This was the press in which Anglo-Irish regiments, fighting on the British side, soon expressed themselves with Kiplingesque fervour for the cause of Queen and Empire:

When Kruger heard the regiment was landed at Cape Town 'De Wet', says he, 'we're bate', says he, 'They've sent out the South Downs.'

Says de Wet, 'If that's a fact, me son, we'd better quit the Rand,

For them South Down Mileeshy is the terror of the land'. 4

(McCracken, 1996:7)

The Irish Figaro of 11 August 1900 published a ballad suggesting the complete identification of the sentiments of the Fifth Dublin Fusiliers with the imperial enterprise:

We are leaving dear old Dublin

The gallant famous fifth;

We're going to the Transvaal

Where the Boers we mean to shift.

We are the sons of Erin's Isle -

Modern Musketeers:

The famous Fifth Battalion

Of the Dublin Fusiliers.

Let this conflict be a warning

To all Britannia's foes;

Not to tease her furious lion

As on his way he goes.

For if they do, they'll find they're wrong

And won't get volunteers

To stand in the face of a Regiment

Like the Dublin Fusiliers.

(McCracken, 1995: 10-11)

4 Written by Lt. Col. R.H. Wallace 
Notice the uncompromising identification of "the sons of Erin's Isle" with the goals of "Britannia". The gallantry and military successes of Irish regiments caused such a stir that traditional fears of Irish nationalist symbols which had arisen during earlier Irish uprisings (e.g. in 1798) were apparently overcome to the extent that Queen Victoria personally intervened to approve the formation of an elite corps of Irish Guards as an Irish complement to the existing elite Guards regiments (Davey, 1978:144), and also "directed that the shamrock shall be worn on March 17 [St Patrick's Day] to commemorate the gallantry of Irish soldiers in South Africa (Boyce, 1995:268). This was doubtless a political strategy to engender loyalty and undermine the notion that Irishness was incompatible with fidelity to the British Crown. The response of the nationalist, William O'Brien, to this gracious act of the Queen was to comment that Queen Victoria was a "lady who comes to typify all that is most hateful in English rule" (Boyce, 1995:268). In South Africa, F.W. Reitz, a former President of the Orange Free State, obviously keen to exploit the discord between Irish loyalists and nationalists, commented ironically on the Queen's decision with his own version of "The Wearing of the Green":

They tell me that good honest Pat,

By favour of the Queen,

Has got the right - as well he might -

To wearing of the Green.

Ah, Patrick Atkins, how your breast

Must swell with pride and joy

To think that $\mathrm{Mr}$ Chamberlain

Has found his Irish boy!

Ah! yes bedad! the Irish lad

Full many a fight has won

For Saxon despots, who at home,

Won't trust him with a gun.

For ages long he's suffered wrong,

And yet he thinks it's right -

Dragged through the mud - to shed his blood

In every English fight.

(Davitt, 1902:34; Van Wyk Smith, 1978:83)

The term "Patrick Atkins" itself taunts the Irish soldiers for having become archetypal defenders of the British Empire and its ideals in the Kipling mould.

\section{A displaced struggle: the war as an Irish fight for Irish causes}

As far as Irish nationalists were concerned, involvement in the war was undeniably inspired less by sympathy for the Boers, than antipathy towards the English. William Redmond, brother of the nationalist parliamentary leader, 
declared uncompromisingly with regard to the war in South Africa: "We have but one object - the interest of Ireland. We shall be absolutely frank and brutally selfish" (Davey, 1978:137, quoting the Morning Leader of 18 December 1900). Once again popular verse bears this feature out, for example in an anonymous four-stanza songsheet, entitled, "The new song for the Boers":

$O$ God of battles aid them,

Who smite our oldest foe;

Make strong each blade for Right arrayed,

When war's red trumpets blow.

(McCracken, 1995:106)

The Old Testamental ring of the lines and the invocation of a righteous God on the side of the nationalists, suggest the merging of nationalism and religion which has always characterised (and still does characterise) the lrish struggle, but which is in any case, of course, typical of war-time propaganda.

$O^{\prime}$ Casey describes an enthusiastic crowd in the streets of Dublin, singing of their longing "To strike one blow for you, dear land,/ To strike one blow for you" (O'Casey, 1949:308). The same impulse - to fight the enemy of Ireland lay behind the formation of the Irish Brigades, which participated actively in the war on the Boer side. The First Irish Brigade (as it was somewhat vaingloriously called in spite of the small number of men involved) was organized in 1899 by Irish miners working on the Witwatersrand. It was commanded by Col. John Blake, an Irish-American West Point graduate who had arrived in South Africa in 1895 , but the moving spirit behind it was the eventual second-in-command, Major John MacBride, who, of course, later became the husband of Maud Gonne and a hero of the 1916 uprising. MacBride, who had also emigrated to South Africa in 1895, had started several months prior to the outbreak of hostilities to organize resident Irishmen for possible military service in the event of a war. The Transvaal government duly recognized the Brigade and naturalized its members (so that they would not legally be rebels against the British crown and would be entitled to the rights of prisoners-of-war) and the founding of the brigade was formalized by the issuing of a grandiose manifesto, emphasizing again the opportunity to fight Ireland's enemy, declaring that "The Government of the Transvaal, being now threatened with extinction by our ancient foe, England, it is the duty of all true Irishmen to throw in their lot with the former" and militantly concluding, "England has been the vampire that drained Ireland's life blood for centuries, now her difficulty is Ireland's opportunity" (Monick, 1989:58-61, 78).

The Brigade was warmly embraced by Maud Gonne's Irish Transvaal Committee who encouraged young Irishmen to go out to South Africa to join it (McCracken, 1995:106). Gonne also arranged for the presentation of a green flag, gold-fringed, with a harp in the centre and emblazoned with the legend, 
"Our Land - Our People - Our Language", originally designed for the projected Fenian rising in Connaught in 1867, to the Brigade (Monick, 1989:65). This gesture confirms the appropriation of the war for Irish purposes: the Irish Brigade in South Africa is perceived as a natural successor to earlier Irish rebels against British rule in Ireland, with Irish interests at heart and an Irish cause to fight.

A second and smaller Irish Brigade was formed in early 1900 under the command of an Irish-Australian, Arthur Lynch, a civil engineer and graduate of Melbourne University, who had arrived in South Africa in 1899 as war correspondent for the Paris periodical, Le Joumal, but shortly after decided to join the fray (Monick, 1989:86), calling on his countrymen to remember that "Irishmen who fall in this war will be joined in Irish memories for ever with Sarsfield, with Wolf Tone, and with Robert Emmett" (Lynch, 1903:16)

Most of the emotional attention in Ireland was, however, directed at "MacBride's Brigade" as it was popularly known, and was orchestrated by no less a figure than Arthur Griffith, editor of the United Irishman and later President of the Irish Free State. Griffith had spent some years in the Transvaal, prior to the war, and now threw in his full poetic weight behind the Irish War effort. Griffith's ballads again underline the Irish interest in the war as an Irish struggle against England. This is from his version of "The wearing of the green":

In far-off Africa today the English fly dismayed,

Before the flag of green and gold borne by MacBride's brigade ...

With guns and bayonets in their hands, their Irish flag on high

As down they swept on England's ranks and rang their battle cry:

'Revenge! Remember '98 and how our fathers died!

We'll pay the English back today', cried fearless John.

MacBride (Monick, 1989:63)

There is no mention of the Boers or the particular issues of this war. The ballad talks about Ireland, England and old scores to be settled between them.

Griffith also wrote the lyrics for the Brigade's Anthem. Apart from fleeting, token references to the Southern Cross and "Afric's soil", the song also focuses entirely on Ireland's struggle against England:

From Shannon, Lagan, Liffey, Lee

On Afric's soil today -

We strike for Ireland - brave old Ireland -

Ireland, boys, hurrah!

(Monick, 1989:64) 


\section{Boer War historiography as weapon in the lrish struggle}

Another prominent figure in the Irish nationalist movement to be involved in the war, was Michael Davitt of the Land League, who resigned his seat in parliament and travelled to South Africa to report on the war for the Freeman's Joumal. His account of the war culminated in a hefty volume, The Boer Fight for Freedom, published in 1902 (Davey, 1978:138-139). Once again rhetoric becomes the means to wage the struggle against England. With a bitterness suggesting strong partisanship, Davitt starts off his history by dismissing the "enlightened" aims, claimed for the war by Britain, and points to the "richest gold mines in the world" as the actual mercenary cause (Davitt, 1902:1), echoing John Redmond's statement in Westminster that "the world at large owes a great debt to these two little Republics for showing, in this degraded age, that there are other things to fight for than gold" (O'Brien, 1910:103). In direct contrast to this stand the views put forward by another writer of Irish extraction, Sir Arthur Conan Doyle ${ }^{\mathbf{5}}$, better known as the creator of Sherlock Holmes, in another hefty tome, The Great Boer War, as well as in his later defence of the British war-effort, The War in South Africa: Its cause and conduct. Admittedly Doyle starts his discussion of the causes of the war with the statement, "Gold had been known to exist in the Transvaal before, but it was only in 1886 that it was realised that the deposits which lie some thirty miles south of the capital are of a very extraordinary and valuable nature" (Doyle, 1902:23), admitting by implication the fundamental significance of the Transvaal gold deposits with regard to the origins of the war, but thereafter he toes the official imperial line by focusing his explication of the origins on the grievances of the Uitlander population on the Rand, concluding: "That these Uitlanders had very real and pressing grievances no one could possibly deny" (Doyle, 1902:24). On describing the role of the Dublin Fusiliers and Connaught Rangers in the Battle of Colenso, "desperate men who saw themselves helplessly led and hopelessly beaten", Davitt cannot refrain from pointing out that these were mainly "AngloIrish" (Davitt, 1902: 265), while, when it comes to MacBride's Irish Brigade, he declares hımself incapable of doing "justice to this small body of Irishmen, who in helping to prevent the consummation of one of the greatest and most sordid crimes of human history, have rendered an honourable service to the race to which they belong" (Davitt, 1902:317). Again in direct contrast, Doyle dismisses the pro-Boer Irish Brigade as "an Irish - or more properly an IrishAmerican - corps" (Doyle, 1900:82), intimating that these were not true Irishmen, while he sings the praises of the "Irishmen" in the famous Irish regiments, stating that "amid that army of valiant men there were none who held such a record. 'Their rushes were the quickest, their rushes were the longest and

5 Sir Arthur Conan Doyle was born in Edinburgh, Scotland, but of Roman-Catholic Irish extraction (De Kock, 1968:51). 
they stayed the shortest time under cover' ..." (Doyle, 1900:284). Davitt and Doyle, equally partisan, represent the two points of view, nationalist and loyalist, that divided Irish opinion, not only with regard to this war, but with regard to Ireland's place and role within the Empire in general. The distinction between loyalist Irish and nationalist Irish in terms of "them" and "us", of enemies in a war, is a rhetorical foreshadowing of the bitter internecine strife that was to dominate Irish history in the twentieth century. Although the war to some extent acted as a catalyst in drawing the lines of hostility, a certain fluidity and ambiguity in Irish loyalties and commitments would continue until the Easter Rising of 1916. At the outbreak of the First World War one finds for example an Irish nationalist like Thomas Kettle, collecting arms in Belgium for (anti-English) Irish volunteers, suddenly switching his efforts to address recruiting meetings in Ireland, supporting the war effort (Boyce, 1995:283). The execution of the leaders of the 1916 rebellion, however, inevitably turned them into martyrs and made the Rising a watershed in Irish history, causing the divisions which had been suggested by the Anglo-Boer War to become immutable, political divides which could never again be crossed (cf. Boyce, 1995:285).

Nothing was to foreshadow the tragedy of 1916 and the troubles of the twenties as poignantly as the Battle of Talana or Dundee, in October 1899, where Irishman met Irishman, as the Royal Dublin Fusiliers encountered the Irish (proBoer) Brigade in battle (Monick, 1989:68-71). (Irish troops would also be present on both sides at the Battle of Colenso and at Ladysmith.) Michael Davitt describes how the "Irish Tommies" panted up a hill, shouting to the "flying Fenians" to stand. "They stood: the Tommies came on to the very crest of the hill, when up sprang Blake and his command, and sent the contents of their Mausers almost point blank into the ranks of the Royals ..." (Davitt, 1902:290). Col. Blake, commander of the Irish Brigade, relates how eighty-five of the one hundred and ninety-six Irish soldiers (fighting on the British side) that were captured by his men at Dundee, begged to be allowed to join the Brigade in order to fight with the Boers (Blake, 1903:64). The poignancy of this early conflict in the history of contemporary Irish civil strife is bitterly underscored by the ironically humorous verse that was the inevitable rhetorical outcome:

On the mountain side the battle raged, there was no stop or stay; Mackin captured Private Burke and Ensign Michael Shea,

Fitzgerald got Fitzpatrick, Brannigan found O'Rourke,

Finnigan took a man named Fay - and a couple of lads from Cork.

Sudden they heard McManus shout, 'Hands up or I'll run you through',

He thought it was a Yorkshire 'Tyke' - 'twas Corporal Donaghue!

McGarry took O'Leary, O'Brien got McNamee,

That's how the 'English fought the Dutch' at the Battle of Dundee.

The sun was sinking slowly, the battle rolled along;

The man that Murphy 'handed in', was a cousin of Maud Gonne, 
Then Flanagan dropped his rifle, shook hands with Bill McGuire, For both had carried a piece of turf to light the schoolroom fire ... Dicey brought a lad named Welsh; Dooley got McGurk; Gilligan turned in Fahey's boy - for his father he used to work. They had marched to fight the English - but Irish were all they could see That's how the 'English fought the Dutch' at the Battle of Dundee. (Cavanagh, 1924:123-126; McCracken, 1995:112-113)

\section{Conclusion}

It is probably significant that nothing more lasting than doggerel verse and partisan historiography emerged from Irish participation in the Boer War. Perhaps this is the consequence of the fact that in many ways the Boer War was, for Ireland, a displaced struggle, a war of rhetoric and propaganda. Even for many of the Irish combatants in the war, the significance of the struggle was - as has been demonstrated - at one remove. It is perhaps not surprising then that the literary products rarely rose above the level of propaganda. In South Africa, the suffering of the Boer people, the loss of political autonomy, the deaths of 26000 Boer women and children in concentration camps, led to the first significant literary movement in Afrikaans and the emergence of important poets like Leipoldt, Marais and Totius. Ireland had to wait another sixteen years for its own tragedy, and a terrible beauty to be born. ${ }^{6}$

\section{Works ciłed}

Blake, Col J.Y.F. 1903. A West Pointer with the Boers. Boston : Angel Guardian Press.

Boyce, D George 1995. Nationalism in Ireland. Third edition London \& New York : Routledge

Brown, Malcolm. 1972. The Politics of Irish Literature. London: Allen \& Unwin.

Cavanagh, Jas. A. 1924. Adventures of an Insurance Agent. Cape Town : Juta.

Cullingford, Elizabeth. 1981. Yeats, Ireland and Fascism London : Macmillan

Davey, Arthur. 1978. The British Pro-Boers (1877-1902). Cape Town : Tafelberg.

Davitt, Michael. 1902. The Boer Fight for Freedom New York \& London : Funk \& Wagnalls.

De Kock, W J (ed-in-chief) 1968. Dictionary of South African Biography, Vol I. Cape Town : Tafelberg for the HSRC.

Doyle, Sir Arthur Conan. 1900. The Great Boer War. London : Smith \& Elder.

Doyle, Sir Arthur Conan 1902 The War in South Africa: Its cause and conduct. London : Smith \& Elder.

Gregory, Lady. 1974 [1903]. Poets and Dreamers: Studies and Translations from the Irish Gerrards Cross : Colin Smythe

Harkness, David 1995 Ireland in the Twentieth Century: Divided Island London Macmillan

6 "A terrible beauty is bom": the refrain of Ycats's poem "Easter 1916", inspired by the Easter Rising in Dublin in that year 
Kipling, Rudyard. 1919. Rudyard Kipling's Verse 1885-1918, Vol. II London: Hodder \& Stoughton.

Lower, J.A. 1970. A Nation Developing: A Brief History of Canada. Toronto : Ryerson.

Lynch, Arthur Alfred. 1903. Return to an address of the honourable the House of Commons London: HMSO, Eyre \& Spottiswoode

McCracken, Donal. 1996. Irish identity in twentieth-century South Africa. In: McCracken, Donal P. (ed.) Ireland and South Africa in Modern Times. Durban: The Ireland and Southern Africa Project. p. 7-45

McCracken, Donal P. 1995. The Irish Literary Movement, Irish Doggerel and the Boer War Etudes Irlandaises, 22:97-115, Autumn.

McCracken, J.L 1978. Irish Nationalists and South Africa. Christiaan de Wet-Annale, 5:159184, October.

Malins, Edward, \& Purkins, John. 1994. A Preface to Yeats London \& New York : Longman.

Monick, S 1989. Shamrock and Springbok: The Irish Impact on South African Military History 1689-1914. Johannesburg : South African Irish Regimental Association.

O'Brien, R. Barry (ed.) 1910. Home Rule: Speeches of John Redmond, M.P. London : Unwin.

O'Casey, Sean 1949. Pictures in the Hallway. London : Macmillan.

Spies, S B. 1980. Women and the War. In: Warwick, Peter (ed.) The South African War. Harlow, Essex : Longman. p. 161-185.

Van Wyk Smith, Malvern. 1978. Drummer Hodge: The Poetry of the Anglo-Boer War (18991902). Oxford : Clarendon. 